The covered milk-Sample D-looked and smelt quite fresh.] The bacteriological condition was as follows :--

\begin{tabular}{|c|c|c|c|c|c|c|c|c|}
\hline Sample. & $\begin{array}{c}\text { Number } \\
\text { of aerobic } \\
\text { organisms } \\
\text { capable } \\
\text { of growth } \\
\text { on gelatin } \\
\text { at room } \\
\text { temper- } \\
\text { ture after } \\
40 \text { hours. }\end{array}$ & $\begin{array}{l}\text { Growth } \\
\text { in pep- } \\
\text { tone } \\
\text { broth at } \\
37^{\circ} \mathrm{C} \text {. } \\
0.0001 \text { c.c. }\end{array}$ & \multicolumn{2}{|c|}{$\begin{array}{l}\text { Glucose } \\
\text { broth } \\
\text { at } 370 \mathrm{C} \text {. } \\
0.0001 \mathrm{c.c} .\end{array}$} & \multicolumn{2}{|c|}{$\begin{array}{c}\text { Lactose } \\
\text { broth } \\
\text { at } 37^{\circ} \mathrm{C} . \\
0001 \mathrm{c.c} .\end{array}$} & $\begin{array}{c}\text { Agar } \\
\text { slope at } \\
370^{\circ} \mathrm{C} . \\
0.0001 \mathrm{c.c} .\end{array}$ &  \\
\hline $\begin{array}{c}\mathrm{C} \text { (ex- } \\
\text { posed } \\
\text { milk). }\end{array}$ & $72,600,000$ & $\begin{array}{l}\text { Growth } \\
\text { + scum. }\end{array}$ & $\begin{array}{c}\text { Acid. } \\
+\end{array}$ & $\begin{array}{c}\text { Gas. } \\
\text { No } \\
\text { note. }\end{array}$ & $\begin{array}{c}\text { Acid. } \\
+\end{array}$ & $\begin{array}{c}\text { Gas. } \\
+\end{array}$ & $\begin{array}{c}70 \\
\text { colonies. }\end{array}$ & $\begin{array}{c}\text { Acid } \\
+\end{array}$ \\
\hline $\begin{array}{c}\mathrm{D} \\
\text { (covered } \\
\text { milk). }\end{array}$ & $24,640,000$ & $\begin{array}{l}\text { Growth } \\
+ \text { scum. }\end{array}$ & + & $\begin{array}{c}\text { No } \\
\text { note. }\end{array}$ & ++ & + & $\begin{array}{c}7 \\
\text { colonies. }\end{array}$ & $\begin{array}{c}\text { No } \\
\text { note. }\end{array}$ \\
\hline
\end{tabular}

These results again prove a marked and rapid deterioration of milk exposed to flies, there being in the course of 24 hours no fewer than approximately $40,000,000$ more bacteria per cubic centimetre in the exposed milk, and ten times as many organisms capable of growing on agar at the body temperature $\left(37^{\circ} \mathrm{C}\right.$. $)$. In round numbers the exposed milk showed 700,000 bacteria per cubic centimetre capable of growing at $37{ }^{\circ} \mathrm{C}$. against only 70,000 bacteria in the case of the milk protected from flies.

A further experiment showed that under anaerobic conditions the exposed milk (C) contained spores which on development in milk produced both gas and clot, while the covered milk (D) showed clot alone but no gas.

Remarks. -The importance of protecting milk from flies is illustrated by these experiments. It can readily be understood that the larger the number of flies the greater would be the pollution. It is not difficult to realise how in a flyridden district diarrhœal diseases may be in excess unless care is taken to see that food-supplies (especially milk) are protected from the contaminating attentions of flies.

The experiments were undertaken on the lines of natural conditions obtaining in houses, so as to include the natural factors of symbiosis or antagonism of bacteria already existing in an ordinary milk-supply. A point I wish to make is that the number of putrefactive bacteria in milk is of great importance. The chemical changes produced in milk by, say, thousands of putrefactive bacteria may perhaps not be sufficient to cause serious diarrhœa, while the chemical changes produced by millions of such bacteria may conceivably be very prejudicial and excite acute diarrhcea.

A rord as to treatment. - The facts indicate the wisdom of early expulsion of the bacteria and their toxic products by a large dose of castor oil which should, in my judgment, be followed by small doses-say, ten grains- of sulphate of soda every two hours dissolved in sterilised (boiled) water. No food should be given for six or eight hours, and then only steritised whey, commencing with small quantities, gradually increasing same. The utmost care should be taken that all milk used for artificially fed infants should at all times be scrupulously protected from fly contamination, especially in dealing with an infant suffering from or convalescent from epidemic diarrhœea.

Norwich.

\section{A CASE OF TRAUMATIC EXOPHTHALMOS.}

By DAVID RANKEN, M.B., B.S. LOND. \& DURH., M.R.C.S. ENG., L.R.C.P. LOND.,

HOUSE SURGEON TO THE SPECTAL DEPARTMENTS, ROYAI VICTORIA INFIRMARY, NEWCASTLE-ON-TYNE.

THE patient was brought to the Royal Victoria Infirmary, Newcastle-on-Tyne, on August 13th last, with the following history. He was driving a waggon whilst sitting on the shaft when the horse, which happened to be young and restive, lashed out suddenly with one of its hind legs, striking him in the face and knocking him over. His left eye was immediately dislocated forward beyond the lids, and directly afterwards he lost consciousness. About a quarter of an hour afterwards he came to himself and was sick, but felt no pain. The eye still remained protruding from the orbital cavity. Within the next hour he was brought to the hospital and whilst being examined again vomited.
On admission the patient was quite conscious and was able to answer questions intelligently. His pulse was good. There was epistaxis from both nostrils. On the left cheek there were several gashes, one extending into the ala of the nose, and obviously produced by the horse's hoof. The left eyeball protruded well beyond the lids. There was hyphæmia and the bulbar conjunctiva was torn all round in a neat circle quite close to the corneal margin. The sclera was intensely injected and the lids were swollen but not lacerated. No sight whatever remained in the eye. The left cheek was painful to the touch and one was unable to make out by palpation the normal outline of the left side of the face. Crepitus of the nasal bone and the nasal process of the superior maxilla was present. The patient had great pain and difficulty on attempting to open his mouth. The teeth outline was normal and there was no hæmorrhage either from the mouth or ears. Attempts to replace the eye were desisted from because of the pain they caused.

Under chloroform the eye could be easily replaced in the orbital cavity, but slight pressure on the lids was sufficient to luxate it forwards again. One was able to detect with the finger in the left nostril great comminution of the inner wall of the antrum of Highmore. The outline of the orbital plate of the superior maxilla on the face was lost. It was decided to remove the eye, and the recti muscles were divided in the ordinary way. On exposing the optic nerve it was found to be loose, and after dividing the rest of the structures connecting the eyeball with the orbital cavity one was able to draw out exactly two inches of nerve, still firmly connected with the eyeball, but with the cranial end severed as if with a sharp knife. Very little bleeding ensued. The wounds in the cheek were sutured with horse-hair, a sponge was left over the left eyelids, and the nostrils were loosely packed with gauze wrung out of a perchloride of mercury solution.

Recovery was uninterrupted. There was some serous oozing from the eye and nostrils during the next few days. Ten days later the patient left the hospital. He was seen eight weeks after the operation when he stated that he had been working then for some weeks past. The wounds in his cheek were quite healed, his left orbital cavity presented the appearance as after an ordinary excision, and he could open his mouth quite wide.

Fracture of the anterior fossa of the skull with severance of the optic nerve is not a common accident, but when complicated with complete exophthalmos becomes one of extreme rarity. The average length of the optic nerve is 5 centimetres, or about two inches, and hence it must have been severed in this case just at its origin from the optic chiasma, in all probability when passing through the optic foramen. The fracture of the superior maxilla on that side was an additional complication.

This case was under the care of Mr. J. D. Wardale, ophthalmic surgeon to the hospital, and I am indebted to him for permission to publish these notes.

Newcastle-on-Tyne.

\section{EXTENSION OF A PLEURAL EFFUSION} TOWARDS THE SOUND SIDE IN

\section{A STILL-BORN CHILD}

CORRESPONDING TO GROCCO'S PARAVERTEBRAL TRIANGLE.

BY ROBERT D. KETTH, M.A., M.D. ABERD.,

IECTURER ON PHYSIOLOGY, THE S'TRAITS MEDICAL SCHOOL, SINGAPORE; AND

ARTHUR KEITH, M.D. ABERD., F.R.C.S. ENG. CONSERVATOR OF MUSEUM, ROYAL COLIEGE OF SURGEONS OF ENGLAND

THE subject of this note was a still-born child, probably of Chinese parentage, found in the streets of Singapore and investigated by us with a view of discovering the cause of the anasarcous condition of its tissues. In this we were not successful; the ductus venosus which was found absent in a similar case was here present; the heart also was normally formed ; the tissues of the body, especially the kidneys, were extensively invaded with leucocytes.

Our main reason for recording the case is that it supports those who regard Grocco's paravertebral triangle of dulness as due to a direct extension of the pleural fluid or contents from the diseased towards the sound side. A reference to 